\title{
Impact of Integrated Nutrient Management on Seed Production of Onion (Allium cepa L.) cv. Sukhsagar
}

\author{
S. Tamang*, A. Bandyopadhyay, N. Chattopadhyay and D. K. Ghosh (LKN)
}

Department of Plantation Spices, Medicinal and Aromatic crops, Faculty of Horticulture, Bidhan Chandra Krishi Viswavidyalaya, Mohanpur-741252, Nadia, West Bengal, India

*Corresponding author

\section{A B S T R A C T}

An experiment was carried out at Horticultural Research Station, Mondouri, Bidhan Chandra Krishi Viswavidyalaya, Nadia, during Rabi season of 2017-18 and 201819.The onion cultivar "Sukhsagar" was taken under the study. Three levels of nitrogen $\left(100,125,150 \mathrm{~kg} \mathrm{ha}^{-1}\right)$, one level of phosphorus $\left(80 \mathrm{~kg} \mathrm{ha}^{-1}\right)$ and three levels of

\section{Keywords}

$\mathrm{B}$ : C ratio, onion, nitrogen, phosphorous, potassium, seed yield

Article Info

\section{Accepted:}

20 May 2021

Available Online:

10 June 2021 potassium $\left(80,100,120 \mathrm{~kg} \mathrm{ha}^{-1}\right)$ along with FYM @ $5 \mathrm{t} \mathrm{ha}^{-1}$ were included in the investigation. There were altogether 9 treatments viz. $\mathrm{T}_{1}-\mathrm{N}_{100} \mathrm{P}_{80} \mathrm{~K}_{80}+\mathrm{FYM} @ 5 \mathrm{t}$ $\mathrm{ha}^{-1}, \mathrm{~T}_{2}-\mathrm{N}_{125} \mathrm{P}_{80} \mathrm{~K}_{80}+\mathrm{FYM} @ 5 \mathrm{t} \mathrm{ha}^{-1,} \mathrm{~T}_{3}-\mathrm{N}_{150} \mathrm{P}_{80} \mathrm{~K}_{80}+\mathrm{FYM} @ 5 \mathrm{t} \mathrm{ha}^{-1}, \mathrm{~T}_{4}-$ $\mathrm{N}_{100} \mathrm{P}_{80} \mathrm{~K}_{100}+\mathrm{FYM} @ 5 \mathrm{t} \mathrm{ha}^{-1}, \mathrm{~T}_{5}-\mathrm{N}_{100} \mathrm{P}_{80} \mathrm{~K}_{120}+\mathrm{FYM} @ 5 \mathrm{t} \mathrm{ha}^{-1}, \mathrm{~T}_{6}-\mathrm{N}_{125} \mathrm{P}_{80} \mathrm{~K}_{100}+$ FYM@5 tha ${ }^{-1}, \mathrm{~T}_{7}-\mathrm{N}_{125} \mathrm{P}_{80} \mathrm{~K}_{120}+\mathrm{FYM} @ 5 \mathrm{tha}^{-1}, \mathrm{~T}_{8}-\mathrm{N}_{150} \mathrm{P}_{80} \mathrm{~K}_{100}+\mathrm{FYM} @ 5 \mathrm{t}$ $\mathrm{ha}^{-1}$ and $\mathrm{T} 9-\mathrm{N}_{150} \mathrm{P}_{80} \mathrm{~K}_{120}+\mathrm{FYM} @ 5 \mathrm{tha}^{-1}$. The experiment was laid out in RBD with three replications. Among different treatments combination maximum plant height was observed with $\mathrm{T}_{6}-\mathrm{N}_{125} \mathrm{P}_{80} \mathrm{~K}_{100}+\mathrm{FYM} @ 5 \mathrm{t} \mathrm{ha}^{-1}(39.73 \mathrm{~cm})$, maximum number of leaves was observed with $\mathrm{T}_{5}-\mathrm{N}_{150} \mathrm{P}_{80} \mathrm{~K}{ }_{120}+\mathrm{FYM} @ 5 \mathrm{t} \mathrm{ha}^{-1}$ (29.35) and maximum basal girth of spike $(8.05 \mathrm{~cm})$ was recorded underT $\mathrm{T}_{8}\left(\mathrm{~N}_{150} \mathrm{P}_{80} \mathrm{~K}_{100}+\mathrm{FYM}\right.$ ( $\left.5 \mathrm{t} \mathrm{ha}^{-1}\right)$. The yield attributing parameters like maximum number of inflorescence (4.75), maximum spike length $(108.01 \mathrm{~cm})$, maximum umbel diameter $(7.10 \mathrm{~cm})$, maximum seed yield per umbel(3.55 gm), 1000 seed weight $(4.55 \mathrm{~g})$, seed yield per plot $(300.54 \mathrm{~g})$ and projected seed yield $\left(587.06 \mathrm{~kg} \mathrm{ha}^{-1}\right)$ were observed with $\mathrm{T}_{7}\left(\mathrm{~N}_{125}\right.$ $\mathrm{P}_{80} \mathrm{~K}_{120}+\mathrm{FYM} @ 5 \mathrm{t} \mathrm{ha}^{-1}$ ).From seed production maximization and $\mathrm{B}: \mathrm{C}$ ratio (3.33) point of view, the most effective treatment was $\mathrm{T}_{8}\left(\mathrm{~N}_{150} \mathrm{P}_{80} \mathrm{~K}_{100}+\mathrm{FYM} @ 5 \mathrm{t} \mathrm{ha}^{-1}\right)$ under new alluvial soil of west Bengal.

\section{Introduction}

Onion (Allium cepa L.) the "Queen of the kitchen" belongs to family Alliaceae is one of the most important commercial vegetable cum spices crop of India as well as in the World
(Selvaraj, 1976). The outstanding characteristic of onion is its pungency, which is due to presence of a volatile oil known as allyl propyl disulphide (Yawalkar,1985). The red colour is because of the pigment anthocyanins and yellow colour is due to quarcetin (Debnath et 
al., 2008). India is the second largest producer of onion in the world with an area of 11.73 lakh ha and production of 189.28 lakh tons next only to China with the productivity of $16.13 \mathrm{t} \mathrm{ha}^{-1}$ a (Anon., 2016). In West Bengal onion is cultivated over an area of 25.31 thousand ha, production of 369.20 thousand MT with productivity of $14.59 \mathrm{t} \mathrm{ha}^{-1}$ (NHB, 2015-16). It is a herbaceous annual for edible bulb production and biennial for seed production.

Seed is the primary input, without which the increase in production of any crop cannot be expected. India needs around 9400 tons of onion seeds annually (Directorate of Onion and Garlic Research). NPK fertilizers are the chemical compounds applied to promote plant growth. The application of nitrogen with different doses increased plant growth and yield of onion (Patel et al., 1992). Phosphorus has its beneficial effect on early root development, plant growth, yield and quality. Potassium plays an important role in crop productivity. Keeping all the views in mind an experiment was conducted to find out the best possible combination of $\mathrm{N}, \mathrm{P}$ and $\mathrm{K}$ along with fixed dose of FYM on seed yield of local cultivar (Sukhsagar) of onion in new alluvial plains of West Bengal.

\section{Materials and Methods}

The experiment was carried out at the HRS, Mondouri, BCKV, Mohanpur, Nadia, West Bengal during the year 2017-18 and 2018-19. The cultivar "Sukhsagar" was under taken the study. The soil at the experimental field was Gangetic alluvial with sandy clay loam texture, good water holding capacity, well drained with moderate soil fertility status and soil $\mathrm{P}^{\mathrm{H}}$ of 6.9. The organic carbon, total nitrogen, available phosphorus and potassium contents are $0.63,0.084$ percent, $18.07 \mathrm{~kg}$ ha1 , respectively. Treated mother bulbs were planted within second fortnight of November each year in $2 \times 2.5 \mathrm{~m}$ plot at $40 \times 25 \mathrm{~cm}$ spacing. Three levels of each nitrogen $\left(100,125,150 \mathrm{~kg} \mathrm{ha}^{-1}\right)$, one level of phosphorus $\left(80 \mathrm{~kg} \mathrm{ha}^{-1}\right)$ and three levels of potassium (80, $100,120 \mathrm{~kg} \mathrm{ha}^{-1}$ ) along with fixed dose of FYM @ $5 \mathrm{t} \mathrm{ha}^{-1}$ were included in the investigation. The doses of fertilizer were adjusted with application of urea, single super phosphate and muriate of potash. There were altogether 9 treatments. All experimental plots received a uniform dose of FYM at 5 tones ha1 , half dose of nitrogen, full dose of phosphorus and half dose of potash as basal and remaining half dose of each nitrogen and potash was applied after 30 days after sowing (DAS) as top dressing. Need based irrigation and eco friendly plant protection measures were under taken. Diseased and off types plants were rouged out before flowering for quality seed production. Harvesting was done during $1^{\text {st }}$ fortnight of April.

The observations were recorded on ten randomly tagged plants from each plot on different growth and yield parameters like number of leaves and plant height $(\mathrm{cm})$ at 60 DAS, number of inflorescence, number of spike/ plant, length of spike $(\mathrm{cm})$, basal girth $(\mathrm{cm})$ diameter of umbel $(\mathrm{cm})$ at 90 DAS, seed weight ( $\mathrm{g}$ per umbel), seed weight $(\mathrm{g})$ per plot and projected seed yield $\left(\mathrm{Kgha}^{-1}\right)$ during harvesting (125 DAS). The projected yield per hectare was calculated on plot yield basis after deducting 15 percent area utilized for channel, ridges etc.Net return or profit was calculated by subtracting production cost from the gross values of the produce. Prices used for harvest products were average prices observed during the experimental period.

The benefit cost ratio (BCR) was calculated by dividing the net return by the production cost. The significance of different sources of variation was tested by error mean square by fisher snedecor's ' $F$ ' test at probability level of 0.05.Statistical analysis for each variable 
was conducted as per the procedure given by Gomez and Gomez (1984).

\section{Results and Discussion}

Data presented in the table 1 revealed that irrespective of any treatment and year, within the treatments influence of $\mathrm{N}, \mathrm{K}$ and FYM on different growth parameters of onion better growth was observed when higher dose of $\mathrm{N}$, $\mathrm{K}$ and FYM were applied with different combinations. Pooled data reflect that maximum plant height of $39.73 \mathrm{~cm}$ was recorded in $T_{6}$ where $\mathrm{N}$ was applied in higher dose along with higher dose of $\mathrm{K}$ closely followed by $\mathrm{T}_{3}(39.70 \mathrm{~cm})$. Even in year wise data also the same pattern was followed. On the other hand pooled minimum plant height $(37.85 \mathrm{~cm})$ was recorded where dose of $\mathrm{N}$ and $\mathrm{K}$ were comparatively low $\left(\mathrm{T}_{1}\right)$. Pooled data analysis showed that in case of number of leaves per plant, $\mathrm{T}_{9}$ recorded maximum (29.13) followed by $\mathrm{T}_{3}$ (28.70) whereas, minimum in $\mathrm{T}_{5}$ (23.57). In year wise data analysis it was clear that $\mathrm{T}_{9}$ recorded maximum 28.9 and 29.35 number of leaves per plant during 2017 and 2018 respectively. Similarly, $\mathrm{T}_{5}$ recorded minimum 22.68 and 24.45 numbers of leaves per plant during the same period of experimentation. Regarding basal girth of the spike pooled data noted that $\mathrm{T}_{8}$ recorded maximum basal girth of $8.05 \mathrm{~cm}$ followed by $\mathrm{T}_{7}(8.0 \mathrm{~cm})$ which are at par with each other and $\mathrm{T}_{4}$ recorded minimum basal girth of $7.0 \mathrm{~cm}$. From year wise data analysis it was clear that, $\mathrm{T}_{7}$ recorded maximum basal girth $(7.85 \mathrm{~cm})$ and minimum basal girth $(6.85 \mathrm{~cm})$ under $\mathrm{T}_{4}$ during 2017 . On the other hand during second year maximum basal girth $(8.55 \mathrm{~cm})$ was recorded under $\mathrm{T}_{6}$ and minimum $(7.15 \mathrm{~cm})$ in $\mathrm{T}_{4}$. The number of inflorescence per plant recorded maximum (4.75) in $T_{7}$ and minimum in $\mathrm{T}_{4}$ (4.10) under pooled analysis. Data presented in Table -2 on yield parameters of onion like spike length, umbel diameter, seed weight per umbel, Seed weight per plot and Projected seed yield per hectare. The maximum spike length of $108.01 \mathrm{~cm}$ was recorded under treatment $T_{7}$ and $T_{5}$ recorded minimum spike length of $97.55 \mathrm{~cm}$ per plant under pooled analysis. In year wise data analysis it was clear that during 2017, maximum spike length of $103.65 \mathrm{~cm}$ was registered under treatment $T_{7}$ closely followed by $\mathrm{T}_{9}(103.55 \mathrm{~cm})$ which are at par with each other and minimum spike length was found under $\mathrm{T}_{5}(96.65 \mathrm{~cm})$.

On the other hand in 2018, maximum spike length $(112.35 \mathrm{~cm})$ was recorded under treatment $T_{7}$ followed by $T_{8}(110.85 \mathrm{~cm})$ and minimum spike length of $97.65 \mathrm{~cm}$ was recorded under treatment $T_{1}$. In case of umbel diameter it was clear from the same table that $\mathrm{T}_{7}$ recorded maximum umbel diameter of 7.10 $\mathrm{cm}$ closely followed by $\mathrm{T}_{9}(7.06 \mathrm{~cm})$ and minimum in $T_{2}(5.74 \mathrm{~cm})$ under pooled data. The year wise data analysis revealed that, in the first year maximum umbel diameter of $6.96 \mathrm{~cm}$ was recorded under $\mathrm{T}_{9}$ closely followed by $\mathrm{T}_{7}$ and $\mathrm{T}_{8}(6.85$ and $6.80 \mathrm{~cm}$, respectively). However, in 2018 maximum umbel diameter of $7.35 \mathrm{~cm}$ was recorded under $\mathrm{T}_{7}$ followed by $\mathrm{T}_{9}, \mathrm{~T}_{6}$ and $\mathrm{T}_{8}(7.16 \mathrm{~cm}, 7.15 \mathrm{~cm}$ and $7.15 \mathrm{~cm}$, respectively) and minimum in $\mathrm{T}_{2}$ $(5.85 \mathrm{~cm})$.

Maximum seed weight per umbel $(3.55 \mathrm{~g})$ was recorded under $\mathrm{T}_{7}$ followed by $\mathrm{T}_{9}(3.37 \mathrm{~g})$ and minimum $(2.56 \mathrm{~g})$ in $\mathrm{T}_{1}$ considering pooled data. In individual year wise data analysis, pointed out that, in 2017 maximum seed weight per umbel $\left(3.15 \mathrm{~g}\right.$ ) was noted in $\mathrm{T}_{7}$ followed by $\mathrm{T}_{6}(2.95 \mathrm{~g})$ and minimum in $\mathrm{T}_{1}$ (2.35g). Similarly, in 2018, maximum seed weight of per umbel was recorded under treatment $\mathrm{T}_{7}(3.95 \mathrm{~g})$ followed by $\mathrm{T}_{9}(3.87 \mathrm{~g})$ and minimum in $\mathrm{T}_{1}(2.76 \mathrm{~g})$. Pooled data analysis revealed that maximum seed weight of $300.54 \mathrm{~g}$ per plot was registered under $\mathrm{T}_{7}$ and minimum (217.63g per plot) under treatment $\mathrm{T}_{1}$. 
Table.1 Impact of integrated nutrient management on plant height, no. of leaves, basal girth of spike and No. of inflorescence of onion cv. Sukhsagar

\begin{tabular}{|c|c|c|c|c|c|c|c|c|c|c|c|c|}
\hline \multirow[t]{2}{*}{ Treatments } & \multicolumn{3}{|c|}{$\begin{array}{l}\text { Plant Height } \\
(\mathrm{cm})\end{array}$} & \multicolumn{3}{|c|}{ No. of leaves } & \multicolumn{3}{|c|}{$\begin{array}{l}\text { Basal girth of spike } \\
(\mathbf{c m})\end{array}$} & \multicolumn{3}{|c|}{ No. of inflorescence } \\
\hline & 2017 & 2018 & Pooled & 2017 & 2018 & Pooled & 2017 & 2018 & Pooled & 2017 & 2018 & Pooled \\
\hline $\mathbf{T}_{1}$ & 37.55 & 38.15 & 37.85 & 26.15 & 25.65 & 25.91 & 7.25 & 7.85 & 7.55 & 3.85 & 4.65 & 4.25 \\
\hline $\mathbf{T}_{2}$ & 38.65 & 39.25 & 38.95 & 26.45 & 27.25 & 26.85 & 7.45 & 7.85 & 7.65 & 4.11 & 4.25 & 4.18 \\
\hline $\mathbf{T}_{\mathbf{3}}$ & 39.85 & 39.55 & 39.70 & 28.55 & 28.85 & 28.70 & 7.15 & 7.65 & 7.40 & 4.05 & 4.55 & 4.30 \\
\hline $\mathbf{T}_{4}$ & 37.85 & 38.35 & 38.10 & 25.25 & 26.35 & 25.80 & 6.85 & 7.15 & 7.00 & 4.15 & 4.05 & 4.10 \\
\hline $\mathbf{T}_{5}$ & 38.26 & 38.55 & 38.41 & 22.68 & 24.45 & 23.57 & 7.65 & 8.15 & 7.90 & 4.40 & 4.65 & 4.53 \\
\hline $\mathbf{T}_{6}$ & 39.65 & 39.8 & 39.73 & 27.55 & 27.85 & 27.70 & 7.65 & 8.55 & 8.10 & 4.15 & 4.45 & 4.30 \\
\hline $\mathbf{T}_{7}$ & 39.25 & 39.55 & 39.40 & 27.95 & 28.25 & 28.10 & 7.85 & 8.15 & 8.00 & 4.85 & 4.65 & 4.75 \\
\hline $\mathbf{T}_{8}$ & 39.35 & 39.65 & 39.50 & 28.25 & 28.85 & 28.55 & 7.75 & 8.35 & 8.05 & 4.15 & 4.45 & 4.30 \\
\hline $\mathbf{T}_{9}$ & 39.80 & 39.55 & 39.68 & 28.90 & 29.35 & 29.13 & 7.65 & 8.25 & 7.95 & 4.15 & 4.25 & 4.20 \\
\hline $\operatorname{S.Em}( \pm)$ & 0.04 & 0.02 & 9.77 & 0.03 & 0.02 & 6.84 & 0.02 & 0.02 & 1.95 & 0.01 & 0.01 & 1.09 \\
\hline C.D. $(P=0.05)$ & 0.11 & 0.06 & 28.64 & 0.10 & 0.07 & 20.07 & 0.05 & 0.06 & 5.71 & 0.03 & 0.03 & 3.21 \\
\hline
\end{tabular}

$\left(\mathrm{T}_{1}-\mathrm{N}_{100} \mathrm{P}_{80} \mathrm{~K}_{80}+\mathrm{FYM} @ 5 \mathrm{tha}^{-1}, \mathrm{~T}_{2}-\mathrm{N}_{125} \mathrm{P}_{80} \mathrm{~K}_{80}+\mathrm{FYM} @ 5 \mathrm{tha}^{-1}, \mathrm{~T}_{3}-\mathrm{N}_{150} \mathrm{P}_{80} \mathrm{~K}_{80}+\mathrm{FYM} @ 5 \mathrm{tha}^{-1}, \mathrm{~T}_{4}-\mathrm{N}_{100} \mathrm{P}_{80} \mathrm{~K}_{100}+\mathrm{FYM} @ 5 \mathrm{tha} \mathrm{F}^{-1}, \mathrm{~T}_{5}-\mathrm{N}_{100} \mathrm{P}_{80} \mathrm{~K}_{120}+\right.$ FYM @ $5 \mathrm{tha}^{-1}, \mathrm{~T}_{6}-\mathrm{N}_{125} \mathrm{P}_{80} \mathrm{~K}_{100}+\mathrm{FYM} @ 5 \mathrm{tha}^{-1}, \mathrm{~T}_{7}-\mathrm{N}_{125} \mathrm{P}_{80} \mathrm{~K}_{120}+\mathrm{FYM} @ 5 \mathrm{tha}^{-1}, \mathrm{~T}_{8}-\mathrm{N}_{150} \mathrm{P}_{80} \mathrm{~K}_{100}+\mathrm{FYM} @ 5 \mathrm{tha}^{-1}$ and $\mathrm{T}_{9}-\mathrm{N}_{150} \mathrm{P}_{80} \mathrm{~K}_{120}+\mathrm{FYM}_{0} @ 5 \mathrm{tha}$ $\left.{ }^{1}\right)$ 
Table.2 Impact of integrated nutrient management on spike length, umbel diameter, seed weight and projected seed yield of onion cv. Sukhsagar

\begin{tabular}{|c|c|c|c|c|c|c|c|c|c|c|c|c|}
\hline \multirow[t]{2}{*}{ Treatments } & \multicolumn{3}{|c|}{$\begin{array}{l}\text { Spike length } \\
\text { (cm) }\end{array}$} & \multicolumn{3}{|c|}{$\begin{array}{l}\text { Umbel diameter } \\
(\mathrm{cm})\end{array}$} & \multicolumn{3}{|c|}{$\begin{array}{l}\text { Seed weight } \\
\left(\text { g plot }^{-1}\right)\end{array}$} & \multicolumn{3}{|c|}{$\begin{array}{l}\text { Projected seed yield } \\
\left(\mathrm{kg} \mathrm{ha}^{-1}\right)\end{array}$} \\
\hline & 2017 & 2018 & Pooled & 2017 & 2018 & Pooled & 2017 & 2018 & Pooled & 2017 & 2018 & Pooled \\
\hline $\mathbf{T}_{1}$ & 99.07 & 97.65 & 98.36 & 6.16 & 6.65 & 6.41 & 213.46 & 221.79 & 217.63 & 432.78 & 449.78 & 441.28 \\
\hline $\mathbf{T}_{2}$ & 99.65 & 102.66 & 101.16 & 5.62 & 5.85 & 5.74 & 222.15 & 229.65 & 225.90 & 449.75 & 473.92 & 461.84 \\
\hline $\mathbf{T}_{\mathbf{3}}$ & 103.65 & 105.08 & 104.37 & 6.41 & 6.65 & 6.53 & 228.30 & 239.26 & 233.78 & 453.4 & 485.77 & 469.59 \\
\hline $\mathbf{T}_{4}$ & 97.90 & 99.78 & 98.84 & 6.35 & 6.55 & 6.45 & 242.37 & 248.27 & 245.32 & 465.56 & 483.88 & 474.72 \\
\hline $\mathbf{T}_{5}$ & 96.65 & 98.45 & 97.55 & 6.45 & 6.85 & 6.65 & 254.33 & 265.29 & 259.81 & 492.61 & 525.41 & 509.01 \\
\hline $\mathbf{T}_{6}$ & 102.45 & 111.40 & 106.93 & 6.75 & 7.15 & 6.95 & 255.65 & 305.41 & 280.53 & 518.42 & 603.62 & 561.02 \\
\hline $\mathbf{T}_{7}$ & 103.65 & 112.35 & 108.01 & 6.85 & 7.35 & 7.10 & 285.15 & 315.92 & 300.54 & 545.47 & 628.64 & 587.06 \\
\hline $\mathbf{T}_{8}$ & 103.15 & 110.85 & 107.00 & 6.80 & 7.15 & 6.98 & 253.45 & 282.67 & 268.06 & 509.71 & 582.74 & 546.23 \\
\hline $\mathbf{T}_{9}$ & 103.55 & 110.25 & 106.90 & 6.96 & 7.16 & 7.06 & 285.79 & 298.28 & 292.03 & 519.71 & 595.78 & 557.75 \\
\hline $\operatorname{S.Em}( \pm)$ & 0.02 & 0.09 & 25.95 & 0.01 & 0.012 & 1.68 & 0.20 & 0.19 & 66.43 & 0.21 & 0.22 & 131.36 \\
\hline C.D. $(P=0.05)$ & 0.05 & 0.27 & 76.09 & 0.03 & 0.035 & 4.92 & 0.57 & 0.57 & 194.80 & 0.61 & 0.63 & 385.21 \\
\hline
\end{tabular}

$\left(\mathrm{T}_{1}-\mathrm{N}_{100} \mathrm{P}_{80} \mathrm{~K}_{80}+\mathrm{FYM} @ 5 \mathrm{tha}^{-1}, \mathrm{~T}_{2}-\mathrm{N}_{125} \mathrm{P}_{80} \mathrm{~K}_{80}+\mathrm{FYM} @ 5 \mathrm{tha}^{-1}, \mathrm{~T}_{3}-\mathrm{N}_{150} \mathrm{P}_{80} \mathrm{~K}_{80}+\mathrm{FYM} @ 5 \mathrm{t} \mathrm{ha}^{-1}, \mathrm{~T}_{4}-\mathrm{N}_{100} \mathrm{P}_{80} \mathrm{~K}_{100}+\mathrm{FYM}_{0} @ 5 \mathrm{tha}{ }^{-1}, \mathrm{~T}_{5}-\mathrm{N}_{100} \mathrm{P}_{80} \mathrm{~K}_{120}+\right.$ FYM @ $5 \mathrm{t} \mathrm{ha}^{-1}, \mathrm{~T}_{6}-\mathrm{N}_{125} \mathrm{P}_{80} \mathrm{~K}_{100}+\mathrm{FYM} @ 5 \mathrm{t} \mathrm{ha}^{-1}, \mathrm{~T}_{7}-\mathrm{N}_{125} \mathrm{P}_{80} \mathrm{~K}_{120}+\mathrm{FYM} @ 5 \mathrm{tha}^{-1}, \mathrm{~T}_{8}-\mathrm{N}_{150} \mathrm{P}_{80} \mathrm{~K}_{100}+\mathrm{FYM} @ 5 \mathrm{tha}^{-1}$ and $\mathrm{T} 9-\mathrm{N}_{150} \mathrm{P}_{80} \mathrm{~K}_{120}+\mathrm{FYM} @ 5 \mathrm{tha}$ $\left.{ }^{1}\right)$ 
Table.3 Impact of integrated nutrient management on economics of onion seed production cv. Sukhsagar

\begin{tabular}{|c|c|c|c|c|c|}
\hline Treatments & $\begin{array}{c}\text { Projected } \\
\text { seed yield } \\
\left(\mathrm{kgha}^{-1}\right)\end{array}$ & $\begin{array}{l}\text { Gross return } \\
\quad\left(\operatorname{Rs~ha}^{-1}\right)\end{array}$ & $\begin{array}{c}\text { Cost of } \\
\text { production } \\
\left(\operatorname{Rs~ha}^{-1}\right)\end{array}$ & $\begin{array}{l}\text { Net profit } \\
\left(\text { Rs ha }^{-1}\right)\end{array}$ & $\begin{array}{l}\text { Benefit cost } \\
\text { ratio }\end{array}$ \\
\hline T T $1-N_{100} P_{80} K_{80}+F Y M @ 5 h^{-1}$ & 441.28 & 202988.80 & 61589.31 & 141399.49 & 2.29: 1 \\
\hline$T_{2}-N_{125} P_{80} K_{80}+$ FYM @ $5 \mathrm{tha}^{-1}$ & 461.84 & 212446.40 & 61776.81 & 150669.59 & 2.43: 1 \\
\hline $\mathbf{T}_{3}-\mathbf{N}_{150} \mathbf{P}_{80} \mathbf{K}_{80}+$ FYM @ $5 \mathrm{tha}^{-1}$ & 469.59 & 216011.40 & 62389.31 & 153622.09 & 2.46: 1 \\
\hline$T_{4}-N_{100} P_{80} K_{100}+$ FYM @ $5 \mathrm{tha}^{-1}$ & 474.72 & 218371.20 & 61776.81 & 156594.39 & 2.53: 1 \\
\hline$T_{5}-\mathbf{N}_{100} P_{80} K_{120}+$ FYM @ $5 \mathrm{tha}^{-1}$ & 509.01 & 234144.60 & 62389.31 & 171755.29 & 2.75: 1 \\
\hline$T_{6}-N_{125} P_{80} K_{100}+F Y M @ 5 h^{-1}$ & 561.02 & 258069.20 & 61776.81 & 196292.39 & $3.17: 1$ \\
\hline$T_{7}-N_{125} P_{80} K_{120}+F Y M @ 5 t^{-1}$ & 587.06 & 270047.60 & 62389.31 & 207658.29 & 3.33: 1 \\
\hline $\mathrm{T}_{8}-\mathrm{N}_{150} \mathbf{P}_{80} \mathrm{~K}_{100}+\mathrm{FYM} @ 5 \mathrm{tha}^{-1}$ & 546.23 & 251265.80 & 62389.31 & 188876.49 & 3.02: 1 \\
\hline T T $T_{9}-\mathbf{N}_{150} P_{80} K_{120}+$ FYM @ $5 \mathrm{tha}^{-1}$ & 557.75 & 256565.00 & 62389.31 & 194175.69 & $3.11: 1$ \\
\hline
\end{tabular}


The year wise data analysis noted that during 2017 maximum seed weight of $285.79 \mathrm{~g}$ per plot was recorded under $\mathrm{T}_{9}$ closely followed by $\mathrm{T}_{7}(285.15 \mathrm{~g})$ and minimum in $\mathrm{T}_{1}(213.46 \mathrm{~g})$. Similarly, in the second year, maximum seed yield of $315.92 \mathrm{~g}$ per plot was recorded under $\mathrm{T}_{7}$ followed by $\mathrm{T}_{6}(305.41 \mathrm{~g})$ and minimum seed yield of $221.79 \mathrm{~g}$ per plot was recorded under treatment $\mathrm{T}_{1}$.

The maximum projected seed yield $(587.06 \mathrm{~kg}$ $\mathrm{ha}^{-1}$ ) was recorded treatment $\mathrm{T}_{7}$ followed by $\mathrm{T}_{6}\left(561.02 \mathrm{~kg} \mathrm{ha}^{-1}\right)$ and $\mathrm{T}_{9}\left(557.75 \mathrm{~kg} \mathrm{ha}^{-1}\right)$. However minimum projected seed yield of $441.28 \mathrm{~kg} \mathrm{ha}^{-1}$ was observed under $\mathrm{T}_{1}$ from the pooled data. In year wise data analysis, $\mathrm{T}_{7}$ recorded maximum projected seed yield of $545.47 \mathrm{~kg} \mathrm{ha}^{-1}$ followed by $\mathrm{T}_{9}\left(519.71 \mathrm{~kg} \mathrm{ha}^{-1}\right)$ and $\mathrm{T}_{6}\left(518.42 \mathrm{~kg} \mathrm{~kg} \mathrm{ha}^{-1} / \mathrm{ha}\right)$ during 2017 and minimum projected seed yield of $432.78 \mathrm{~kg}$ $\mathrm{ha}^{-1}$ was recorded under $\mathrm{T}_{1}$. In the second year also the same trend was followed like first year. In 2018, maximum projected seed yield of $628.64 \mathrm{~kg} \mathrm{ha}^{-1}$ was recorded under $\mathrm{T}_{7}$ followed by $\mathrm{T}_{6}\left(603.62 \mathrm{~kg} \mathrm{ha}^{-1}\right)$ and $\mathrm{T}_{9}$ $\left(595.78 \mathrm{~kg} \mathrm{ha}^{-1}\right)$ and minimum in $\mathrm{T}_{1}(449.78 \mathrm{~kg}$ $\left.\mathrm{kg} \mathrm{ha}^{-1}\right)$.

Data presented in table 3 revealed that, highest gross return of Rs. 270047.60 per hectare, maximum net return of Rs.207,658.29 per hectare with highest $\mathrm{B}$ : $\mathrm{C}$ ratio of 3.33:1 was found under $\mathrm{T}_{7}\left(\mathrm{~N}_{125} \mathrm{P}_{80} \mathrm{~K}_{120}+\mathrm{FYM} @ 5 \mathrm{tha}{ }^{-}\right.$ $\left.{ }^{1}\right)$ towards onion seed production of local cultivar Sukhsagar.

From the results revealed that the higher dose of nitrogenous fertilizer might influence the vegetative growth of the plants by increasing the plant height, number of leaves, basal girth of the spike, number of inflorescences etc but it might not increase the seed yield per umbel, seed yield per ha alone. The role of potassium in association with nitrogen in seed production was also important. From the tables of yield parameters it was clear that maximum seed yield per umbel, seed yield per plot and projected seed yield per ha were recorded under treatment $\mathrm{T}_{7}$ where NPK was applied @ 125: 80: $120 \mathrm{~kg} \mathrm{ha}^{-1}+5 \mathrm{t} \mathrm{FYM} \mathrm{ha}{ }^{-1}$ which indicates that $\mathrm{N}, \mathrm{K}$ and FYM has a direct influence on seed yield of onion. This is in conformity of the findings of Yadav et al., (2003). They obtained maximum yield (249.12 $\left.\mathrm{q} \mathrm{ha}{ }^{-1}\right)$ and fresh weight of bulb (50.60 g) in onion variety Rasidpura Local with application of $150 \mathrm{~kg} \mathrm{~N} \mathrm{ha}^{-1}$ and $150 \mathrm{~kg} \mathrm{~K}_{2} \mathrm{O}$ $\mathrm{ha}^{-1}$. Pandey and Ekpo (1991), also reported that highest plant height $(63.9 \mathrm{~cm})$ and highest number of leaves (13) were recorded when $\mathrm{N} @ 160 \mathrm{~kg} \mathrm{ha}^{-1}$ was applied in two equal split doses at 10 and 25 days after transplanting. Singh and Chaure (1999) also reported that 6 weeks old onion seedlings supplied with $\mathrm{N} @$ $150 \mathrm{~kg} \mathrm{ha}^{-1}$ showed highest number of leaves per plant with higher plant height. Baloch et al., (1991) reported that in onion highest plant height $(38.5 \mathrm{~cm})$ and number of leaves per plant (17.0) were obtained with $125 \mathrm{~kg} \mathrm{~N}$ $+100 \mathrm{~kg} \mathrm{~K}_{2} \mathrm{O} \mathrm{ha}{ }^{-1}$. In a study Nagaich et al., (1999) also opined that application of $\mathrm{P}_{2} \mathrm{O}_{5}$ @ $60 \mathrm{~kg} \mathrm{ha}^{-1}$ and $\mathrm{K}_{2} 0 @ 80 \mathrm{~kg} \mathrm{ha}^{-1}$ increased the plant height and number of leaves per plant. Bhatia and Pandey (1991) reported that highest seed yield of $20.39 \mathrm{~g}$ plant and $10.27 \mathrm{qha}^{-1}$ ha were recorded with $150 \mathrm{~kg} \mathrm{~N}$ $\mathrm{ha}^{-1}$. Singh et al., (1993) also reported that the highest seed yield $\left(6.64 \mathrm{t} \mathrm{ha}^{-1}\right)$ was recorded when treated with $120 \mathrm{~kg} \mathrm{~N}^{-1}$.

From the above observation it can be concluded that, the role of nitrogen in association with potassium and farm yard manure in seed production of onion plays vital role. From the tables of yield parameters presented in results clearly pointed out that maximum seed yield per umbel, seed yield per plot and projected seed yield per ha were recorded under treatment $T_{7}$ followed by $T_{6}$ which indicated that $\mathrm{N}, \mathrm{K}$ and FYM has direct influence on seed yield of onion. The cost benefit ratio of seed production on onion 
recorded maximum in $\mathrm{T}_{7}-\mathrm{N}_{125} \mathrm{P}_{80} \mathrm{~K}_{120}+$ FYM@ $5 \mathrm{t} \mathrm{ha}^{-1}$ (3.33:1) followed by $\mathrm{T}_{6}$ $\mathrm{N}_{125} \mathrm{P}_{80} \mathrm{~K}_{100}+\mathrm{FYM} @ 5 \mathrm{t} \mathrm{ha}{ }^{-1}(3.17: 1)$ and lowest in $\mathrm{T}_{1}-\mathrm{N}_{100} \mathrm{P}_{80} \mathrm{~K}_{80}+\mathrm{FYM} @ 5 \mathrm{t} \mathrm{ha}^{-1}$ $(2.29: 1)$.

\section{References}

Anonymous, 2016. Annual Report, Directorate of Onion and Garlic Research, ICAR, Rajgurunagar, Pune.

Baloch, M. A., Baloch, A. F. and Ansari, A. H. 1991. Growth and yield response of onion to different Nitrogen and Potassium fertilizer combinations levels. Sarhad J. Agriculture, 7(2):6266.

Bhatia, A. K. and Pandey, U. C. 1991. Effect of planting methods, fertility levels and spacing on seed production of Kharif onion. Research and Development Reporter, 8(1): 10-16.

Debnath, S., Boo Ho, Hwang, S. J., Bae, C. S., 2008. Extraction and characterization of some natural plant pigments. Industrial crops and products, 40: 129135.

Gomez, K. A. and Gomez, A. A. (1984). Statistical Procedures in Agricultural Research. $2^{\text {nd }}$ Ed., John Wiley and Sons, New York, USA., pp 680.

Nagaich, K. N; Trivedi, S. K. and Rajesh, L. 1999. Effects of phosphorus fertilization in onion (Allium cepa L.). Hort.J., 12(1):25-31
Pandy, U. E and Ekpo, U. 1991. Response of nitrogen on growth and yield of onions (Allium cepa L.) in Maiduguri. Research Development Reporter, 8(1):5-9.

Patil, H. M., Shete, B. T. and Kolekar, P. T. 1992. Effect of integrated nutrient management on growth and yield of onion (Allium cepa L.) seed production. Int. J. Agric. Sci.,3(2): 8386.

Selvaraj, S. 1976. Onion queen of the Kitchen. Kisan world, 3 (12): 32-34.

Singh, J. and Chaure, N. K. 1999. Effect of age of seedlings and nitrogen levels on growth and yield of onion (Allium cepa L). Advance in Horticultural and Forestry, 6 (8):73-77.

Singh, J. P., Singh, M. K. and Singh, R. D. 1993. Growth and yield of onion (Allium cepa L.) bulb as influenced by date of transplanting, nitrogen and potash fertilization. Vegetable science, 20(1): 14-17.

Yadav, K. S., Nehra, B. K. Lakshminarayana, K. Malik, Y. S. and Singh, N. 2003. Role of Azotobacter biofertilizer in seed production of onion. Newslett. National Horticulture Research Development Foundation, 23(3): 1922.

Yawalker, K. S. 1985. In :Vegetable Crops in India, Agri-Horticultural Publishing House, Nagpur, pp.288-563.

\section{How to cite this article:}

Tamang, S., A. Bandyopadhyay, N. Chattopadhyay and Ghosh, D. K. 2021. Impact of Integrated Nutrient Management on Seed Production of Onion (Allium cepa L.) cv. Sukhsagar. Int.J.Curr.Microbiol.App.Sci. 10(06): 629-636. doi: https://doi.org/10.20546/ijcmas.2021.1006.069 